\title{
Bread and Circuses
}

\author{
By Gideon Bachmann
}

Fall 1995 Issue of KINEMA

\section{BREAD AND CIRCUSES: PRESENT AND FUTURE OF THE EUROPEAN CINEMA}

GIDEON Bachmann speaks to Ulrich Gregor, the renowned German historian and critic who organises the long-running Forum series of programmes at the Berlin Film Festival. The conversation took place on 6th June 1995, in Berlin.

GB: How healthy is European cinema? Is it true that its existence is threatened by the conquest of European screens by American movies? Can you see in which direction this form of art -or, if you wish, this branch of business -- is heading? If the threat is real, does the European cinema have a chance, or will it always be a minority pleasure?

UG: The threat certainly exists. It is enough to look at attendance figures: their language is clear. The market for European films in Europe itself has never been lower. Even in those countries traditionally seen as pivots of film art, such as France and Italy, European films command only between 5\% and $10 \%$ of the ticket-sales revenue, and many European films are never seen outside of the festival circuit. It has in fact become a stigma, to be told that one's film is "only" a festival picture.

On the other hand, during the last Cannes Festival in May, the French proclaimed that they now commanded $40 \%$ of their own screens, and that only another $40 \%$ of sales revenues went to US movies. Although one would like to believe them, the figures are incorrect because they do not represent an objective view: France has a substantial government subsidy program and an audience that is trained to appreciate the finer things. In any case, even if the figures should be correct, it must be an exception to the rule, and probably due to the fact that by coincidence some very popular films were made in France this past year.

Is it possible that those films were popular in France because they were made after the American model?

That's a fact hard to prove, and I cannot analyse it in detail. But it is clear that despite such occasional claims, the prospects are dubious. One cannot stop trying, and in fact film-makers are known for their stamina, their insistence and their sense of conviction, which in some cases has made it possible for them to collect funds. Many films made in Europe in the past years were made co-operatively, with a large number of sources tapped in a miscellany of countries. It is still possible to make interesting films with a national identity, although the finance may come from more than one country; films made by directors unwilling to compromise and to give up their artistic or national sense of responsibility. This is probably the only way, today, to create valid cinematographic works of art. Whether the public will pay to see them -- if they get an opportunity to be projected, which means they must first be acquired by a distributor also believes in them -- is another matter.

And then we now have, in most European countries, government or regional subsidy programs, which have, in many eases, saved a national industry from collapse. Just today it was announced that 84 million British pounds have been allocated from national lottery funds to help the British film, its creation, distribution and viewing. (David Puttnam, the well-known British producer, said this was only one of a pair of shoes. What the community of film-makers in England had expected, was not a one-time alimony payment, but permanent tax relief.) And we know, that the relative health of the French film industry is due, in large measure, to the enlightened policy of its government which, among other things, forces French TV channels to show as many French films as it shows American ones. Uniting all the forces that continue to believe in European cinema is an essential part of European culture and collecting funds from all of them -- governments, regions, TV channels, a few courageous individual producers -- is probably the only way today to continue creating a responsible form of film.

The films shown this year in Cannes, for example, prove this fact. Emir Kusturica won the Golden Palm for his Underground (shot in the US, by the way), Theo Angelopoulos got the Jury Prize for Oedipus' Way, Ken Loach was widely lauded for his Land of Freedom on the Spanish Civil War, and Manuel de Oliveira 
was awarded a prize for The Monastery. All of these came into being because international and interorganisational factors funded them. These days it is often the producer who must have the creative urge and the organisational ability to help a film being born. The director in a sense becomes the executor of a producer's will, for different reasons a system not far removed from the Hollywood system in the heydays of the cinema, the days when -- as is again now happening -- the name of the director was often not mentioned in the publicity. All of these films each in their own way, are also true metaphors for our condition and our times -- both Kusturica and Angelopoulos deal in Balkan topics. The importance of these films is not only in what they express, but is to be found in the mere fact of their existence.

We all agree, then, that the talent exists and the potential for continuity. But what is the real situation on the ground? Will these people we all love and appreciate continue to be given the opportunities (read: the money) to continue their labours?

The question should rather be put this way: what will the structure of the European film industry be in the future? At the moment most countries try hard to create incentives for these people to continue exercising their craft, but it is still a matter of how able they are to utilise or to find access to these incentives Much is being done by the TV channels, albeit often under the pressure of their lawgivers, on which they in turn depend.

Do we have, in Europe, enough of these creative producers, able to play the subsidy game with success, or is that success sometimes due to personal friendships and nepotism of the usual kind?

There are quite a few, and we must be very grateful to them. Here in Germany, for example, we have at the moment a company called Pandora, in Frankfurt, who have been very actively supporting, often with their own funds, the kind of cinemas which we seem to be calling "European," although, like the film by Jim Jarmusch shown in Cannes, the work originated in the US. Here in Berlin we have the new subsidy program of the Mark Brandenburg (Berlin lies, as a separate "land," in the middle of the "land" -- read: state -of Brandenburg), which is equipped, in monetary terms, to pour about 20 million Marks a year into film production alone. The fund is administered by a single person, a certain Prof. Keil, who can, by his own decision, alot funds to projects he considers worth subsidizing. Previous to this appointment he was active as a teacher in the local film school. Now he has become one of the pivotal figures in our industry here.

Which country in Europe, to your mind, has the best subsidy policy, and can you name some films which owe their existence to this policy?

Ultimately I think we have the best situation here in Germany, because not only the federal government, but also the governments of the various "lands" make their contributions. This regional form of subsidy is highly developed, with each local authority vying to develop the best method and to supply the most extensive means. Of course, these local authorities hope to underline, in the supported film projects, the specificity of their area and its identity, and to provide labour for its inhabitants. This often results in a complicated procedure, often difficult to penetrate, and quite often it happens that the films which result are not of top quality. So despite the enlightened intent, the final result is often disappointing.

In France, too, the situation is quite good. It suffices to traverse Paris by car to see that the theatres show a large quantity of French productions, and there exists, in France, quite a number of directors working towards the development of new ideas and to create films of quality. In juxtaposition to what happens in many other countries, these creators sincerely work for the cinema, not for television, which in other countries is often considered the final -- and secure -- market for local product. Let's take Olivier Assayas; here is a very young director whom nothing seems to stop. And there are a few like him, all highly commendable and widely exhibited.

France has been considered, for some time now, as the country that has done most to save its own film-makers, and because all the subsidy money is not regional but centrally national, it has been thought of as the country at the forefront of European film-making. Is this still true? France maintains a protectionist policy in controlling its TV programming. The American cinema hasn't been able to make the same inroads here as elsewhere in Europe, since national programming is preferred, by rule. That is a notable economic factor that has helped French cinema greatly. I do not believe that the usual way European governments subsidize their industry, the so-called avance-sur-recettes system (subsidizing on 
the basis of a returnable loan to certain scripted projects), which is also the French system, alone creates a more enlightened result. And don't forget that France enjoys quite a high standard of audience, thus a high standard of viewer demand, easily discernable just by driving up and down the Champs Elysées. Also the fact that Paris is so clearly a capital in the extended sense -- unlike other European capitals -- contributes to this factor. Film culture and the profile of French productions are buoyed up by this demand.

In Germany, for example, other factors diminish the chances for film culture, such as the habit to dub all films instead of subtitling them. A film spoken in a foreign language is largely rejected in Germany, but commonly accepted in France. France really enjoys a long-term tradition of valuable cinema, which cannot be said of most other European countries at the moment. In Italy, also part of the best in European film traditions, the current trend is rather to neglect the serious and to go for the popular. In Germany we seem to have maintained the great chasm between film-makers and public, often bridged only by comedies, where we have made some respectable attempts. The German film is not dead, certainly.

\section{Any examples?}

Well, take The Movable Man by Sinke Woertman, which had a few million viewers in Germany alone, which is remarkable. Or Nobody Loves Me, by Doris Dörrie, not a bad film at all. These films show a consciousness and a feeling for life as reflected in our youngest generations, certainly a legitimate intent. Artistic ideas are born from this intent, and some films have also successfully exploited the theme of the ever-present East-West tensions. Unfortunately the attempt to compromise for the sake of entertainment often imposes itself, and the really artistic work rarely makes it to the screen.

So that the old Roman adage, Bread and Circuses, finds an echo in the business of film? It is still easier to find subsidies for popular themes than for a work by, let's say, Theo Angelopoulos?

Both trends exist. Many of the constituted authorities whose mandate includes film subsidies, prefer to sponsor films with a popular trend, although "what the public wants" is still as elusive as ever and major mistakes occur. But many factors need to be considered, besides the script. Many directors simply command attention through their achieved fame, as is the case with actors promised for a certain project. Stars, as we know, often carry a film to success; even Angelopoulos uses Harvey Keitel, Marcello Mastroianni and Jeanne Moreau in his films. Oliveira has Catherine Deneuve. All this helps. It seems to me that the potential a star provides for the success of a work needs to be exploited, to the benefit of an artistic or engaged picture.

But all these stars already have a tradition of appearing in what we call "author's cinema," including the Americans. Their fame does not rely on what is commonly known as the star system, since they have always appeared in very special movies.

Nevertheless they project the mythical quality of stardom, easily discerned in Cannes, where it was the actors, not the directors, that attracted the crowds. The media, too, which today largely control the way a film is received, clearly went for the stars, not for the directors.

I have, in fact, noted here in Germany, that even the most respectable newspapers in announcing the TV programs, usually omit the name of the director in favour of naming the actors, and then, in second place, describing the content, not the form or artistic quality, unless this is done in a very tongue-in-cheek manner where a film is exposed to ridicule when there is no media appreciation.

The TV-stations themselves, in their publicity, rarely mention directors. It has become difficult to do the most simple filing of film stills, because I have to look up the names of the directors myself, since that's how my filing system is alphabetised. It's an unfortunate trend which I think we must oppose, because even if the name of the director doesn't attract the public, it is nevertheless he (or she) who give the film its shape and express its content in images and sound. It is the ongoing discussion and dialectic of the cinema itself which is at stake: things need advance, change, and the director simply represents the person best-situated to carry these onwards. In fact, at festivals, as opposed to "normal" forms of distribution (festivals are also a form of distribution; often a more intense form than the traditional method via film theatres) the directors do count and are properly honoured and esteemed. Those films in which the directors play a more reduced role, where they are simply the executors of the story supplied by the script (often the executors in the real sense!), in fact interest me less, personally. But of course this other form of cinema, probably what you'd 
call the circus-type, exists and helps to maintain the industry's infrastructure.

In history, there have always been films, like Citizen Kane or Schindler's List (to take an old and a new example) which seem to have been able to combine the bread and the circus -- films that had something to say but entertained and encouraged thought at the same time. Has this sort of "bastard" ideal film ceased to exist? Must it always be just the one or the other?

Take Gianni Amelio who made Thief of Children and Lamerica -- both his films won The European Film Prize. He makes very personal films, deeply rooted in Italian life and topics, which certainly have a very clear identity. Both films earned the critics' kudos and public acclaim, expressed in attendance figures. I am quite happy to see that films of this nature -- not filled with special effects or dealing with imaginary and often cruel worlds -- continue to be made and to succeed. There is no question that Amelio in his work expresses the changes occurring in Europe and the changes in its social and political structures.

As long as we're dealing with the realism inherent in currently successful Italian movies you might wish to mention Nanni Moretti, whose Dear Diary has been widely acclaimed and awarded a number of prizes, besides making money.

Yes, another good sign for the future of the European cinema. Of course, this film is now over a year old. But it is not only full of marvellous ideas, but also masters the rare craft of involving the author, Moretti, in the film itself, as an actor. It's his voice, in fact, that gives this film its (his) personality. A very unusual and fortuitous achievement. Probably if films of this nature didn't occasionally come from Italy, we'd be in the desert. I should add that prizes obtained at film festivals don't usually make much difference to public reaction. Really it's only the Golden Palm in Cannes which sometimes has real power. And the Oscars, of course.

Since you travel a lot in order to prepare the excellent programming you do yearly for the "Forum" and for your repertory cinema Arsenal here in Berlin, you could probably tell us what the situation is like in the Eastern part of the newly reunited Europe?

The prospects there look pretty dim to me. The traditional, centrally-coordinated structures have broken down, but there are not only many good directors who continue to exist, but also themes of great interest that, you might say, "lie in the street," waiting to be picked up as film subjects. In fact, interesting films occasionally manage to be produced, but there is a clear loss of orientation in what direction should one work. The local film industries and the local audiences share a lack of direction and of a firm base. In Russia and other "new" countries of the East the American cinema has made the same inroads as elsewhere in Europe, maybe worse here because one is finally allowed to see what one was prevented from seeing under the totalitarian regimes. The share of local productions in the total revenue from exhibition is even smaller here than in the rest of Europe. Most of the times films can only be made as co-productions with Western countries or TV stations. Many of the films that one manages to see have been co-produced with French money, others with Italian, British or German collaboration. Or American -- so survival has been possible. In fact, it seems to me that in Poland, for example, the situation has recently improved, probably because Polish TV has contributed large sums to local film production. This does not mean that these films are immediately broadcast; first of all, the money is being put up so they can be seen in cinemas. Polish directors have said to me that their viewers prefer Polish to American subjects, but of course I haven't been able to verify this astonishing fact.

Hasn't the thirst for American films, simply because now they are allowed in, waned in the five years that this has been possible? I see that very interesting films now seem to be coming from countries that were not previously known as film providers, such as Romania and Kazakhstan. I know that the Romanian work of directors like Pintille are mostly produced by a French company and that Kazakhstan has an immense wealth heretofore inaccessible to doubtful ventures like cinema, but the fact is that Pintille has remained in Romania and deals, like Amelio in Italy, with social and political themes of his country, and that Kazakhstan has begun to provide production funds to other, formerly Soviet countries like Lithuania, so some form of revival and tenacity appear to be -- precisely under pressure -- present in the East.

This is also true for Hungary and Bulgaria but I believe that the space these films of value take up locally is very fragile. Also from Russia there are occasional surprises, take Burnt by the Sun by Nikita Mikhalkov, which just barely missed receiving the Golden Palm in Cannes in 1994. It's a film that leaves you with a 
strong impression. Mikhalkov is an interesting case. He has some qualities that seem to work for him in the international and specifically the American market. His films are very spectacular and very emotional. But they also raise controversies.

In Czech Republic the situation is not very good; we saw only one film, The Razor Blades, by Zdenek Tyc which we found worth paying attention to. It seems to me that the situation here is difficult. The country is engrossed in a sort of cemetery stillness, because for decades nothing at all went on here, total silence from the film-makers, whereas in Poland and Hungary a certain dissidence was kept alive by occasional film works. In the former GDR, (East Germany), not much happened either, in the eighties, although the GDR was the one place in the world where the documentary was always kept alive and interesting, by courageous directors who tried, within the boundaries of the political limits they could broach, to picture the country the way they saw it, thus expressing hidden criticism of the system. But from the film-industrial point of view, of course, these films played only a very small part. These filmmakers continue to produce significant political documentaries, which naturally never reach our screens. Take Volker Koepp and his film about East Prussia, now part of Poland. It's an immense subject, touching upon the century's most important problem, the transmigrations and displacement of entire populations. Deportations, people pushed one way and the other and placed in camps, a profusion of fates and problems we find daily on our own doorstep. These topics are being revived these days in the wake of the festivities connected to the 50 year anniversary of the end of World War II.

I suppose these topics have an increased importance in Germany, where the people who often caused these transmigrations originated, both under the Nazis and after, and where the reactionary tendencies (along with the eternal problem of guilt) seem to lie very closely under the surface...

Of course it is very difficult, here, to discuss these matters, but if we never begin to discuss them, we will never solve them. There has to be a beginning, even if only in order to return to some form of normality. We can't allow the last survivors to die before we try to understand what has happened or is happening.

All the more surprising, then, that only in the documentary film, which never reaches the large cinema audience, we find this consciousness. It seems strange to me that in an age when cinema is fêted for its 100th anniversary and every child in school knows all about it, directors who already command an audience do not choose this matter as a subject. Spielberg tried, but of course he dealt only with the manifestations of history and not with the ramifications for today. We don't even teach film in ordinary schools! And then we demand that people should go to the cinema, unequipped with the awareness of the subjectivity which is inherent in the medium, always providing subjects predigested by another intelligence and supplying, most of the time on purpose, the emotional reaction, thus pre-empting the individual's own exercise of judgment.

There is a concern, in a few individual feature films, with this problem. Some films about filmmaking exist -- "post-modern," if you wish -- and reality as a point of departure, as we said in the case of Amelio and Moretti, does enter into the cinema of serious creators. In Germany I have just seen Rottwang Must Go by Hans-Christian Blumenberg, a former film critic, which is the story of the trials and tribulations of a former director of the Army Film Studio of the [former] GDR, who has the notion that he must continue to produce films that have social and political significance, and who in today's changed society continues to think so. The film is an ironical satire, full of wit and film -- historical quotes, which personally I adore, but this is a sort of "in-film," a film for people who've got cinema in their veins. Although it hasn't been too successful, it exists, which is what counts. It is entertaining and at the same time intelligent in the way it plays with the ingredients of our filmic traditions and the filmic consciousness that exists today, as you say, almost anywhere. It is modern in the sense that it works creatively with quotes -- filmic quotes -- and utilises the arsenal of media techniques for a droll effect.

Thank you, Mr. Gregor. 


\section{Author Information}

Gideon BACHMANN is a distinguished Europe-based writer, critic, filmmaker and interviewer. He has over the years become internationally known for his writings on Pasolini, Fellini and others. He works out of London and Rome, and he is to be found at most of the world's film festivals acting as translator at press conferences. 